\title{
HARE ON UNIVERSALIZABILITY
}

\author{
PHILIP LEMASTERS \\ Duke University
}

What constitutes a moral judgement as a moral judgement? From the popular press to the most staid academic circles, this question will provoke lively discussion. Unfortunately, such discourse often gives rise to more heat than light. This essay treats one of the more enlightening philosophical debates in recent decades on the answer to that question, an exchange that focused on R. M. Hare's view of the universalizability of moral judgements as articulated in his Language of Morals and Freedom and Reason. Hare's argument, in this early stage of his work, is important due to its emphasis on universalizability within the context of descriptive meaning rules and the requirement of prescriptivity for moral judgements. His treatment of the logic of moral discourse is incisive, as it provides a coherent approach to the nature of ethics.

This essay brings Hare into dialogue with his critics Alasdair Maclntyre, Don Locke, and Peter Singer, who attack his position at foundational points. They ask the most important questions: Must moral judgements be universalizable and prescriptive to be truly moral? If so, is Hare's position trivial? Does his approach bridge the gap between facts and action?

Through the consideration of these criticisms of Hare, this essay seeks to gain a critical perspective on Hare's view of universalizability. The question addressed throughout this essay is "Of what value is Hare's position for understanding the nature of moral judgements?" The explication of Hare's argument and the consideration of his critics' positions provide a rigorous testing of the claim that moral judgements must be universalizable.

Hare suggests that universalizability is a characteristic "which is common to all judgements which carry descriptive meaning" $(1963,10)$. It follows that "any judgement which has descriptive meaning must be universalizable, because the descriptive meaning-rules which determine this meaning are universal rules" $(1963,39)$. The designation of a judgement as universalizable means for Hare "only that it logically commits the speaker to making a similar judgement about anything which is exactly like the subject of the original judgement or like it in the relevant aspects" $(1963,139)$. He understands singular descriptive judgements to be universalizable because they commit "the speaker to the further proposition that anything exactly like the subject of the first judgement, or like it in the relevant respects, possesses the property attributed to it" in the original judgement $(1963,12)$. 
Moral qualities on Hare's view are "supervenient or consequential properties." There must be some descriptive property in virtue of which a thing or an action is judged to be good. It does not make sense to say " $X$ is exactly like $Y$ in all respects, but $X$ is good and $Y$ is not" $(1952,80-81)$. Hare insists that there must be some morally relevant difference between the two cases in order to sustain divergent evaluations of them. One must "either produce (or admit the existence of) some principle which makes him hold different moral opinions about apparently similar cases, or else admit that the judgements he is making are not moral ones" $(1963,102)$.

Hare understands the task of moral questions to be "that of helping us to think better about moral questions by exposing the logical structure of the language in which this thought is expressed" $(1963, v)$. Hence, "offenses against the thesis of universalizability are logical, not moral" $(1963,32)$. The principle of universalizability functions only "to force people to choose between judgements which cannot both be asserted without selfcontradiction. And so no moral judgement or principle of substance follows from the thesis alone" $(1963,32)$.

Hare's view of universalizability is illustrated well in his treatment of the "debtor-creditor" case. In this case, A is in debt to B, and B is in debt to $C$, and the law stipulates that creditors may exact their debts by having their debtors put in prison. When B contemplates the moral judgement "I ought to put A into prison because he will not pay me what he owes," he realizes that such a judgement entails his accepting the principle "Anyone who is in my position ought to put his debtor into prison if he does not pay." $B$ now realizes that if he claims that it is the case that he ought to have $A$ imprisoned, he would be required by the logic of moral language to affirm that $C$ ought to have him (B) imprisoned. Hare comments that, since the prescription "C ought to put me into prison" would commit B to accepting the singular prescription "Let $C$ put me into prison," B cannot accept his original judgement that he (B) ought to have $A$ imprisoned, as he is not willing to accept "Let $C$ put me into prison." Such is the case because "ought" is understood here as being used both universalizably and prescriptively (1963, 90-91).

Hare thinks that the above case is an instance of the rejection of a moral principle because "one of its particular consequences proved unacceptable." The case is a paradigmatic example of the task of ethical theory, "to test the moral principles that suggest themselves to us by following out their consequences and seeing whether we can accept them" $(1963,92)$. In order to make sense of such a case, Hare insists that the facts of the case, the logical framework entailed by the use of the word "ought" (universalizability and prescriptivity), and the inclinations of B concerning what might happen to him or others must be taken into account. Says Hare, "These ingredients enable us, not indeed to arrive at an evaluative conclusion, but to reject an evaluative proposition" (1963, 92-93). 
It is important to observe that for Hare "the crucial case which leads to rejection of the principle can itself be a supposed, not an observed, one." It does not have to be case that $C$ would actually do to $B$ what $B$ wants to do to $A$ in order for $B$ to refrain from taking action against $A$. That $B$ fears action which $C$ might take against him is irrelevant to Hare's position. What is necessary for the strength of the moral argument is that "B should disregard the fact that he plays the particular role in the situation that he does, without disregarding the inclinations which people have in situations of this sort." B's taking into consideration A's interests and inclinations as though they were his own is "what turns selfish prudential reasoning into moral reasoning." Hence, a certain aptitude for imagination and the willingness to use it are also required in moral argument, for the sake of enabling one person to give sufficient attention to the inclinations of others (1963, 93-94).

Hare stresses the point that agreement on the meaning of "ought" does not entail that the persons who agree on the meaning of the word would share necessarily the same moral views. This is the case in that ethics' "bearing upon moral questions lies in this, that it makes logically impossible certain combinations of moral and other prescriptions"; it does not advance substantive moral positions. But despite the fact that it is possible for people to disagree on the facts of a case, to have different inclinations toward a course of events, or to have divergent imaginative capacities, the logic of moral discourse "is an immensely powerful engine for producing moral agreement" $(1963,97)$.

Hare tests the validity of the above "debtor-creditor" argument by considering several ways in which a person in B's situation "might seek to avoid it." First, Hare considers the maneuvers which would depend on B's using the word "ought" in a way that is either not universalizable or not prescriptive "at the cost of resigning from the kind of discussion that we thought we were having with him" $(1963,95)$. Were B to use "ought" prescriptively but not universalizably, B would claim moral justification for putting $A$ into prison while not agreeing that $C$ ought to put $B$ in prison. Hare does not think that he and $B$ would be in moral disagreement in this situation, as B is advocating no universal principle concerning what ought to be done in all cases of this sort. Hare understands $B$ to have violated the logic of moral language by ignoring the requirement of universalizability in moral judgements. Hence, "he has to abandon the claim that he is justifying the action morally, as we understand 'morally'" (1963, 98-99).

He next considers the case in which B might use "ought" universalizably but not prescriptively. Were B refusing to use the term prescriptively, "he could assent to the singular prescription 'Let not $C$ put me into prison for debt, and yet assent also to the nonprescriptive moral judgement 'C ought to put me into prison for debt'." Consequently his desire not to be imprisoned by $C$ would be no obstacle to B's saying that he ought to imprison A. Hare also notes that, were B using "ought" nonprescriptively, 
the statement '"I ought to put A into prison for debt' [would] not entail the singular prescription 'Let me put A into prison for debt'; the moral judgement becomes quite irrelevant to the choice of what to do." In this case, Hare's disagreement with $B$ would be only verbal, "because whereas we should be dissenting from the universalizable prescription 'B ought to put $A$ into prison for debt, this would not be what B was expressing...B would not, by these words, be expressing a prescription at all." B would have violated the logic of the use of moral terms $(1963,99-100)$.

Hare then examines the ways of escape from his treatment of the "debtor-creditor" case which involve "refusing to make positive moral judgements at all in certain cases," while still using "ought" universalizably and prescriptively. By claiming that it is morally indifferent whether or not $B$ imprisons $A$ or by refusing to make any moral judgement in the matter, $B$ would be able to avoid the force of the moral agreement. Hare's argument succeeds only in forcing B "to reject the moral judgement 'I ought to imprison A for debt'." It cannot force B to judge morally $(1963,101)$. But such appeals will have force in the case of a person who will make positive moral judgements in situations concerning the actions of others, but not about his or her own actions, or in some of his or her own decisions, but not in others. The logic of moral reasoning, says Hare, will make it necessary to ask such a person on what principle the distinctions between the different cases are made. The person "must either produce (or at least admit the existence of) some principle which makes him hold different moral opinions about apparently similar cases, or else admit that the judgements he is making are not moral ones." With no morally relevant distinction between the cases to justify different moral judgements, the person would be in violation of the requirement of universalizability for moral judgements $(1963,102)$.

Hare also notes the possibility that B will be so committed to the principle that people who refuse to pay their debts should be imprisoned
that he will contend that $B$ should have $A$ imprisoned and that $C$ should have $B$ imprisoned. The position of such a person, described by Hare as a "fanatic," would "render ineffective the appeal to universalized selfinterest which is the foundation of the argument that we have been considering." A person who is so committed to such an ideal does not mind that his or other people's interests are harmed in the pursuit of the ideal. Hare suggests that B would be more likely to affirm an ideal in such a fanatical way if his role as a debtor were only hypothetical. But by asking $B$ to imagine himself in the situation of the person toward whom an undesired action would be taken, "we might bring him to realize that to hold his principle involved prescribing that things should be done to him, in hypothetical situations, which he could not sincerely prescribe." If such were the case, B would not be able to say that he ought to take action against A. Nevertheless, there remains the possibility that B would 
as a fanatic and affirm that $B$ should imprison $A$ and that $C$ should imprison B for the sake of principle $(1963,103-106)$.

Hare thinks that the most likely strategy that someone in B's position would employ to escape the conclusion that $B$ ought not imprison $A$ if $B$ is not prepared to affirm that $C$ should imprison $B$ is an appeal to the facts of the case. Were $B$ to demonstrate that the case of $B$ and $A$ is different in a morally relevant way from the case of $C$ and $B, B$ would escape the force of the argument. "The difficulty, however, lies in drawing the line between those arguments [for morally relevant factors] ...which are legitimate, and those which are not." Hare reasons that the fact that no two cases are identical in all respects is irrelevant to the argument, "for all we have to do is to imagine an identical case in which the roles are reversed." A morally relevant difference between cases must refer to "a properly universal property," a property that would be at stake in another case in which B played the role of A. Such an argument "will force him to count as morally relevant only those properties which he is prepared to allow to be relevant even when other people have them." Hare insists that this approach eliminates "the attractive kinds of special pleading" concerning why one case is different from another that B might employ to avoid the force of the angument $(1963,106-107)$.

Hare suggest that two points of qualification are necessary to sustain the validity of above test for proposed morally relevant differences between cases. First, when asking $B$ to imagine himself in the place of $A$, the question should be phrased in the form "What do you say (in propria persona) about a hypothetical case in which you are in your victim's position?'" By asking "What do you say?" rather than "'what would you say...if you were he?'," B is constrained by moral logic to submit to the test concerning whether or not "he now holds an opinion about the hypothetical case which is inconsistent with his opinion about the actual case." By asking "What do you say?," we deprive B of the response that his opinion is only hypothetical, not an actual one that he is holding, and therefore irrelevant to his decision about how to treat $A$. Second, Hare stresses that he is not maintaining that B ought not to imprison A simply because $B$ does not want to be imprisoned by $C$. Such a formulation would violate Hare's understanding of the impossibility of deriving an "ought" from an "is." Hare's "point is, rather, that because of his adversion to its being done to him in the hypothetical case, he should not accept the singular prescription that in the hypothetical case it should be done to him, and this, because of the logic of 'ought,' precludes him from accepting the moral judgement that he ought to do likewise to another in the actual case." Hare's argument is one of moral logic: As B, given his inclinations, cannot assent sincerely to a particular singular prescription, he cannot assent to a universal prescription that entails that singular prescription. "Because of this entailment, if he assented to the factual statements lof a casel and to 
the universal prescription, but refused...to assent to the singular prescription, he would be guilty of a logical inconsistency" (1963, 108-109).

Hare understands the relationship between a person's inclinations and his or her prescriptions to be such that a person cannot sincerely say that he or she loathes imprisonment more than anything else in the world and at the same time sincerely say "Let me be put into prison"." An assent to such a prescription would be logically possible only if the person's inclinations had changed. But such inclinations may very well change, as it is logically possible for a person to be a "fanatic," to employ his or her freedom to prescribe "Let me be imprisoned" or "Let me be executed" for the sake of some principle or ideal $(1963,110-111)$.

Now that I have described Hare's view, it is time to give consideration to his critics. The first critic, Alasdair Maclntyre, asserts that Hare has unjustifiably made the logic of a particular moral stance the logic of morality qua morality. In "What Morality Is Not," he challenges Hare's claim that moral judgements must be universalizable and prescriptive. To argue against the requirement of universalizability, he cites Sartre's example of the young French pupil during World War II who had to chose between leaving France to serve under de Gaulle or remaining at home to care for his mother. Sartre used the example to argue that the student might decide on one course of action while allowing that others in similar situations might choose differently without blame. Macintyre asserts that Hare's insistence on the universalizability of moral judgements draws "a line around one area of moral utterance and behaviour and restrict(s) the term to that area" in such a fashion that Sarte's non-universalized moral judgements are ruled out of the moral sphere. Hence, Macintyre argues that only some, not all, moral judgements are universalizable. He indicates that it is entirely possible for someone to make the statement "'I ought to abstain from participation in war, but $I$ cannot criticize or condemn responsible nonpacifists'" as a moral judgement. Such a person might be refusing to legislate for other precisely on moral grounds. To insist, says Macintyre, that all moral judgements must be universalizable is to advance a thesis that "can only be maintained by an a priori and quite unjustifiable restriction upon the word "moral."

Another example offered by Maclntyre in support of his angument is the theological notion of "works of supererogation," deeds of moral heroism that go beyond what is required by universalizable moral maxims. "To say of a man that he did his duty in performing a work of supererogation is to contradict oneself" on Maclntyre's view, as supererogation refers to a realm of moral stringency to which it is not incumbent on anyone to adhere. He comments on Captain Oates' final, self-sacrificial trek into the snow that it does not "make sense to assert that Captain Oates did what he ought to have done." Works of supererogation, for him, do not entail a sort of moral logic that requires universalizability (326-328). 
The main thrust of Macintyre's argument throughout the essay is that the requirement of universalizability is entailed by a certain sort of morality, but that such a requirement is not a logical requirement for all moral reasoning. Says MacIntyre of the argument for a standard of universalizability to ensure consistency between espoused moral principles and particular judgements, "We blame a man for moral inconsistency perhaps, but we do not find what he says meaningless." Rather than a requirement of logic, Maclntyre finds the notion of universalizability to be an embodiment of the liberal political requirement that "everyone shall be judged by the same standard" with impartiality as concerns the person whose action is in question. Maclntyre claims "It is not part of the meaning of 'morality' tout court that moral evaluations are universalizable, but liberals tend to use the word 'morality' in such a way that this is made part of its meaning" (332-333).

Macintyre concludes the article with an argument that, while it is often helpful to begin reflection on a particular moral question with the question "What ought someone like me to do in this kind of situation'," in complex situations phrases "like 'someone like me' or 'this kind of situation' become vacuous." Maclntyre seems to suggest that in situations in which a person finds himself or herself committed to contradictory moral maxims, it is impossible to choose a course of action according to what a similarly perplexed hypothetical person would choose in a similarly confusing hypothetical situation. The implication of MacIntyre's position is that a moral judgement made concerning such a situation would not necessarily be universalizable (335).

Don Locke, the second critic whom we will consider, argues in "The Triviality of Universalizability," that Hare's formulation of the universalizability of moral judgements "seems to collapse into the shattering triviality that cases are alike, morally or in any other respect, unless they are different" (25). Locke recognizes that Hare's view of universalizability is a logical consequence of his claim that moral judgements possess descriptive meaning. But he thinks it trivial to assert that there is some quality of a thing in virtue of which it will be good, bad, or something else: "What follows from the fact that this is good is only that all things which are $X$ are good, where being $X$ logically entails being good" (28).

Locke treats Sartre's example of the French student to display the fact that Hare's approach entails that the student, in saying that he "ought" to do $X$, "must be legislating for everyone; if he had decided that the reasons for joining the Free French outweigh the reasons for staying with his mother, then he had decided that they do so no matter who is placed in his situation." He demonstrates that Maclntyre's argument, that the point of the Sartre example is that the student may decide that he "ought" to do $X$ without blaming someone else in a similar situation for not doing $X$, misses the issue in question. Locke thinks that it is possible for the student to.say 
"As I ought to do $X, I$ judge it wrong for Louis to do $Y$ in a similar situation, but I do not blame him for his decision. It is certainly understandable that Louis would do $Y$, and he is within his rights to do so, but I still think it wrong" (31).

Locke also demonstrates that, were Sartre's student to say "'I believe that $l$ ought to join the Free French but if, in a situation like mine, you sincerely believe that you ought to stay with your mother, then that is what you ought to do--you ought to act differently, even though your situation is the same as mine'," he would not be in violation of Hare's universalizability requirement, as there is a reason in both cases for either staying or leaving. "The claim is not that if 1 ought to do $X$ then there is some reason why anyone ought to do $X$ (Principle of Sufficient Reason), such that anyone else to whom that reason applies ought also to do $X$ (logical consistency)." Locke provides the further example of someone who thinks that he "ought" to see a production of Hamlet because he thinks that he will enjoy the performance. He reasons that, on Hare's view, the person who thinks that he "ought" to see Hamlet is committed to the proposition that anyone in relevantly similar circumstances who would enjoy the performance ought as well to see it. Comments Locke in describing Hare's view, "A reason is a reason for anyone for whom it is a reason, but this is not to say what is obviously false, that a reason for one person is a reason for anyone, that all reasons apply equally to everyone" (32). Locke thinks that Hare's argument serves to establish only that if $D$ ought to be done in virtue of reason $Y$, then $A, B$, and $C$ ought to be done to the extent that $Y$ is applicable to one or more of them. But Hare, for Locke, "has not established that different people ought in the same situations to do the same thing, for the fact that they are different people might mean that the reasons which apply to them are different" due to their inclinations, beliefs, or desires (33-34).

Locke agrees with Macintyre that Hare's insistence on the universalizability of moral judgements is not part of the logic of morality but a particular view of morality that is undergirded by the claim that "we ought not to make exceptions in our own favor" in moral judgements. Locke provides the example of someone who believes in the divine right of kings: a right which applies only to one person at a time. He argues that an affirmation of rule by divine right is a moral principle which makes an exception of a particular individual...here is a principle.... which does not seem to be universal" (37). The advocate of monarchial rule by divine right would affirm that the reason for the monarch's power is that the king is given the power by Cod, and that anyone to whom such power is given ought to reign. But such a reason, Locke points out, applies to only one person. "Inasmuch as there is only one king,...these principles precisely do make exceptions of particular people."

Locke gets to the crux of the matter with his argument that for Hare, while moral judgements presuppose reasons, Hare sets no limit on what can 
be understood as a reason. "All that the argument has shown is that if I believe that I am morally privileged, then I must be able to offer reasons why I am thus privileged." He thinks that Hare's response to his charge would be that reason $X$ (say, "My name is Nimrod $Q$. Poindexter. I should rule because 1 assent to the universal prescription 'Persons named Nimrod $Q$. Poindexter ought to rule.") is not morally relevant for distinguishing between similar cases. Retorts Locke, "to say this is to import a moral element into an argument supposed to be purely logical. All that is required by logic is that I offer some reason; whether you find my reason morally acceptable is neither here nor there" (38-39). On Locke's view, it is false to claim that all moral principles apply to everyone, for Nimrod's claim does not apply to people named Obadiah, and it is trivial to assert that a moral principle applies to those who are within its realm of application. Hare's difficulty, for Locke, is that he takes it for granted that moral principles apply to all people irrespective of who they are without demonstrating how this is the case. "This would be correct only if it were true that moral principles cannot contain references to particular items and individuals...But this...is precisely what Hare does not establish" (39).

Locke's final objection is to Hare's claim "that it is always possible to construct at least a hypothetical case in which the moral principles in question apply to the person who was originally applying them to someone else" as in the "debtor-creditor" case. Locke insists that Hare's approach is faulty in that it ignores the fact that it is impossible to apply a moral principle to someone to whom it does not apply, and that not all moral principles are even hypothetically applicable to those making the judgements. He considers C. C. W. Taylor's example of the white South African who would be asked by Hare to place himself in the situation of a black South African to test the validity of his claim that blacks should be governed by whites. Locke cites the case of the white South African as an example of the fact that it is impossible for one person to become another, to imagine oneself as being fully in his or her situation with his or her background, inclinations, etc... As one person cannot take another's position in a meaningful way in many instances, Locke rejects Hare's universalization test from the "debtor-creditor" case (42).

Peter Singer, our third critic, considers, in "The Triviality of the Debate over 'Is-Ought' and the Definition of 'Moral'," the advantages of universal prescriptivism over descriptivism and "neutralism," the view that there is complete neutrality about the form and content of moral principles such that there are no limits on what may be affirmed as a moral principle. He understands the universalizability requirement to be useful for distinguishing between "the principles on which people might act" to determine "which are not moral principles." Singer cites the case of Jack and Bill who are discussing the merits of spending money on luxuries for themselves or on feeding the starving. Bill is brought by the universalization test to recognize that the prescription "I ought to spend 
money on luxuries and not on feeding the starving" is not acceptable to him when he imagines himself as one of the starving. It is possible that this test might not change Bill's mind due to principles he might hold concerning individual self-sufficiency. But Singer's argument is that, despite the unlikely sacrifice for the sake of an ideal, "the universalization argument does provide a means of linking moral conclusions with statements about suffering, happiness, and other matters which may, with some reservations, be termed 'factual.".

He also recognizes the possibility that someone may opt out of morality as understood in universal prescriptivism by failing to universalize judgements. But what is most important for Singer is his argument that universal prescriptivism bridges the gap between morality and action only for those who would not be moved by a descriptivist account of, say, suffering or happiness, but who will likely be the sort of people who are more concerned with moral ideals than with the interests of themselves or others. "The person who, because he holds the ideal of 'standing on one's own two feet' is able to resist the universalization argument and buy his Mercedes while others starve, is just the sort of person who would not be prepared to act on moral principles, if 'moral' were defined in terms of suffering and happiness, but would be prepared to act on moral principles, defined so that they must be universalizable but can have any content" (56). Singer thinks that a person who does not hold such moral principles, but who is willing to submit to the universalization test, would be just as easily moved to act on moral principles as defined by a descriptivist in terms of suffering or happiness as by the universalization argument.

So the only advantage that universal prescriptivism has over "neutralism" and descriptivism is that "there are some people for whom it can show a logical tie between action and morality" in a way that is superior to descriptivism. A disadvantage to universal prescriptivism is that it cannot provide, for those who are moved to action by it, "a tie between reason, or fact, and morality." Nor, on Singer's view, is universal prescriptivism superior to neutralism in persuading an egoist to act according to universalized principles, as an advocate of universal prescriptivism "would have to use the same arguments that a neutralist can use to get an egotist [who has opted out of the realm of moralityl to take into account considerations other than his own interests." Singer concludes the article with his claim to have demonstrated "that there are limits to what any account of morality can do." He suggests that there is no definition that can bridge the gap between facts and action; that no definition of morality has a real advantage over other definitions; and that debates over the definition of morality and the "is-ought" question "are disputes over words which raise no really significant issues" (56).

Maclntyre, Locke, and Singer have advanced arguments against Hare that seem to strike at the very heart of his position of universalizability. 1 will now examine those arguments in detail in an effort to determine what 
valid critical insight they bring to Hare's view. First, our attention turns to Maclntyre, who begins his critique of Hare with the charge that an insistence on the universalizability of moral judgements is not, as Hare argues, a requirement of the logic of moral language, but rather a particular view of morality that finds its suurce in the fact that Hare is a political liberal who believes that persons should be treated impartially. But Macintyre's critique does not harm Hare's argument, as he never attacks that which undergirds universalizability: the claim that moral judgements have descriptive meaning as they are evaluative judgements that are supervenient on descriptive properties. Since all judgements that possess descriptive meaning are universalizable, it follows that moral judgements, which possess descriptive meaning, are universalizable. Were Macintyre to formulate an argument against this view of supervenience, he might be able to demonstrate inadequacies in how Hare formulates his view. But as he does no more than to assert, in effect, "Morality might be understood differently by someone else," his argument carries little weight. Also it is not the case that Hare's position surreptitiously underwrites liberal political morality, as Hare's is a formal claim about the logic of moral language which may be appropriated by dedicated monarchists, Nazis, or anyone else who is willing to affirm that he or she would accept a disadvantaged position for the sake of principle.

A second attack that Macintyre makes on Hare is that many moral judgements, such as those resulting in acts of supererogation, are by definition not universalizable. But what Macintyre fails to see is that the person who decides to undertake such an act on the grounds that "I ought to do $X^{\prime \prime}$ is constrained by the logic of "ought" on Hare's terms to affirm also "I think that anyone in a situation that is similar to mine in morally relevant respects ought to do X." Macintyre does not provide convincing reasons that people may use "ought" in such a fashion that it is not universalizable simply due to the traditional theological category of works of supererogation. As he does not engage critically Hare's formulation of universalizability via the supervenience of moral judgements on descriptive properties, Maclntyre does not build a case against Hare that is sufficient to sustain his argument on supererogation. In other words, why should we think that Captain Oates had to use "ought" in "I ought to freeze to death for the sake of others given the particulars of my situation" in a way that is different from the use of "ought" in "I ought not to commit murder"? Macintyre does not provide a convincing answer.

Macintyre also argues that it is impossible to place oneself even hypothetically in the situation of another, and that in complex situations it does no good to ask what someone else would do in a similar circumstance. Hence, he concludes that Hare's universalizability thesis is not helpful in moral discernment. But Maclntyre fails to see that Hare is not suggesting that $A$ decide what to do in situation $X$ as though $A$ were really $B$. On the contrary, Hare understands universalizability as a criterion for moral 
judgements to help $A$ identify the morally relevant aspects of a situation so that A will judge in a manner that is consistent with moral logic. The test of universalizability requires imagining that one is in the situation of someone else for the purpose of determining whether one is willing to prescribe universally the relevant moral judgement. If one finds that one is not willing to prescribe such a judgement universally, which would entail prescribing it with reference to oneself in a hypothetical situation, one is prevented by moral logic from carrying out the judgement against another. Hare neither suggests nor requires the translation of one person wholly into another for the sake of sound moral judgement. As Maclntyre fails to see how universalizability functions for Hare, his critique is not forceful.

Now let us examine the views of Locke, who argues that Hare's view of universalizability requires persons only to give reasons that one situation is different from another to justify a different moral evaluation of the appropriate action to be taken in the situations, and that such a claim establishes merely that people who accept the same reasons are logically required to judge similarly. He suggests that Hare has not demonstrated that which he thinks Hare is trying to show: that different people ought to reach the same universalizable moral conclusions in judgements on similar situations. Locke is disturbed that, according to Hare, the particular prescriptions of a king to rule by divine right may be universalized. He also insists that it does not make sense to apply, even hypothetically, a moral judgement to someone to whom it does not apply, such as asking a white South African to imagine that he is black.

These objections by Locke make clear that he fails to take into account that Hare is not attempting to demonstrate that people with different inclinations and values ought to agree morally. To the contrary, Hare is concerned to argue that particular moral agents should make moral judgements in such a fashion that they are willing to affirm that others who are in situations that are similar to theirs in morally relevant respects ought to make the same judgements. In his treatment of the "debtorcreditor" case, Hare insists that the facts of a case, the logic of moral language, and the inclinations of the agent are factors that must be taken into consideration, in making moral judgements. Hare does not argue about what sorts of inclinations or reasons are morally legitimate; instead, he makes a formal case to the effect that agents ought to imagine themselves in situations in which their previously affirmed prescriptions apply to them, and then ask themselves whether they are inclined to universalize the prescriptions or to accept reasons that justify the judgement against them. If they are so inclined, they are free to make such universal prescriptions. If not, they are required by moral logic to refrain. Locke fails to see that Hare proffers the requirement of universalizability as a test for guiding agents in making judgements that are in accordance with the logic of moral language, not as a method that guarantees agreement or praiseworthy moral judgements. 
Hare's argument does not rest on the claim that a person actually sees the moral world through another's eyes in a hypothetical role reversal. But it is Hare's position that universalizability requires an agent at least to attempt to imagine himself or herself in the situation of the other party. Hare acknowledges that the agent, say, an Afrikaner or an absolute ruler, might opt out of the universalizability test and hence no longer be making a moral judgement. Or such an agent might be a "fanatic" and insist that, even if he or she were black or a peasant, that he or she should be ruled by others. Hence, Locke's objections do not weaken Hare's position. They serve only to highlight the particular sort of universalizability that Hare advocates.

Finally, let us scrutinize the arguments of Singer, who is correct that universal prescriptivism does not bridge the gap between "is" and "ought;" but that is not Hare's purpose in advancing the case for universalizability. More interesting is Singer's claim that universal prescriptivism serves as an incentive to action only for those who care more about principles than about facts, such as suffering, and that people who are not concerned with moral principles would be moved to action just as easily by a descriptive appeal to the facts as by the requirement of universalizability. I do not wish to argue with Singer's psychological assumptions about motivation, as I do not know what to make of them. But even if they are valid, it is still the case that Hare's view of universalizability could serve as a guide to persons of both sorts to help them in determining what principles or facts they take to be so morally relevant that they are willing to incorporate them into universal prescriptions. Singer's critique that universal prescriptivism does not tie together neatly reason, fact, and morality can also be met with the response that the sort of moral self-criticism that the requirement of universalizability entails can guide agents in such a fashion that they will formulate reasons more responsibly, interpret the facts of a case more sensitively, and undertake moral reflection in a more consistent manner.

The critiques of Maclntyre, Locke, and Singer are not persuasive against Hare because their arguments do not attack the foundations of his view of universalizability, are focused on points which Hare does not claim for his formulation, or fail to recognize the role that the requirement of universality plays in this thought. As Hare formulates his task, universalizability is "a kind of exploration. We are to go about looking for moral judgements which we can both accept for our own conduct and universalize to cover the conduct of other actual or hypothetical people" $(1963,193)$. Limits are set on the universal prescriptions that people are willing to affirm in light of "the desires and inclinations of the human race" $(1963,195)$. Hare allows for the peculiar judgements of the "fanatic" and the amoral discourse of the person who will not submit to the logic of moral language. Though he does not guarantee that his approach will convince the Nazi or the Afrikaner to be moral in any particular way, Hare's insistence that "we are logically prohibited from making different 
moral judgements about two cases, when we cannot adduce any difference between cases" is an invitation to moral imagination and consistency that will facilitate the moral discernment of those who accept it $(1963,216)$. Seen in this light, Maclntyre, Locke, and Singer should be able to affirm Hare's approach as a tool of self-criticism. 
Selected Bibliography

Hare, R. M. The Language of Morals. Oxford: The Clarendon Press. 1952.

_-. Freedom and Reason. Oxford: The Clarendon Press. 1963.

Locke, Don. "The Trivializability of Universalizability," Philosophical Review 72 (1968): 25-45.

Maclntyre, Alasdair. "What Morality Is Not," Philosophy 32 (1957): 325335.

Singer, Peter. "The Triviality of the Debate over 'Is-Ought' and the Definition of 'Moral.' American Philosophical Quarterly 10 (1973): 5156. 